\title{
E-tailing as an evolution of the distribution channel in tourism ${ }^{1}$
}

\author{
Mauro Cavallone - Michele Modina
}

\begin{abstract}
Purpose of the paper: The paper aims to provide a concrete understanding of the changes that have affected the tourism market. More specifically, the study captures how the structure of industry has transformed and will continue to follow an evolutionary path.

Methodology: In order to examine the characteristics and preferences of e-tailing in tourism, we have conducted a quantitative study with a random sample of Italian and American customers.

Findings: New companies have entered the market, existing ones have revised their strategies, consumers have become more sophisticated when using the Internet as a tool for doing research and finding affordable deals. The evidence emerging from the analysis performed highlights how technological innovation has changed the relationship between company and customer and the buying behaviour of the latter in the tourism industry.

Research limits: The study suffers from a small sample size and a selection process that cannot be representative of the larger population of tourist customers. Hence, the results from the current study cannot be generalized to this wider community.

Practical implications: From the results of an online questionnaire, the paper provides empirical evidence of how the tourism industry can improve the virtual world on the basis of its experiences in the real world.

Originality of the paper: The value of this paper is to update the available knowledge on the distribution channel in tourism industry taking in consideration the recent evolutions of the structure of travel intermediation.
\end{abstract}

Key words: electronic retailing; tourism; e-tourism; distribution channel; communication

\section{Introduction}

Technological innovation and the evolution of consumption patterns have redesigned and are redesigning the tourism industry. The new tools of information and communication technology are characterized by openness, access and user participation, which tend to reshape the paradigm of the relationship between company and customer and the methods of dialogue between the two actors. A growing number of consumers are using the Internet, mobile devices and social media in their personal and professional lives. At the same time, the growth of online sales offers new

1 Best paper for the $18^{\text {th }}$ Toulon-Verona Conference "Excellence in Services",

Palermo (Italy), 31 August - 1 September 2015. 
sinergie Vol. 34, N. 100, 2016

buying opportunities for customers, who can purchase products/services conveniently at affordable prices, but it also raises new questions for companies on how to structure their marketing strategy effectively.

In healthcare, the integration between communication and technology is giving rise to new forms of interaction between doctor and patient. In the retail industry, the development of social commerce is changing the behavior and buying preferences, favoring a continuous exchange of information between company and customer and amongst consumers themselves. In tourism, the introduction of technological applications allows consumers to glimpse a preview of the experiences they will actually have.

Inspired by literature review and empirical analysis, the paper provides a representation of the new forms of interaction in the tourism industry, benefiting from the integration of the new technological tools that facilitate access to information. The study applies the wider literature in e-tailing and tourism in order to ascertain how the structure of the industry has been transformed and how it will continue to follow an evolutionary path. New companies have entered the market, existing ones have revised their strategies and consumers have become more sophisticated when using the Internet as a tool for doing research and for finding affordable deals. From the results of a questionnaire, the paper provides empirical evidence of how the tourist industry can improve the virtual world on the basis of its experiences in the real world. At the same time, it updates the knowledge available on the distribution channel in the tourism industry taking into consideration the recent evolutions of the structure of travel intermediation.

The article is structured as follows: the first section examines the main theoretical contributions on e-commerce, e-tailing and e-tourism. The second analyzes the results of a questionnaire regarding the impact of the Internet on tourist product retailing and the habits of e-tourism players. Based on the empirical results, the final section identifies the key factors that make new technologies a tool for reducing distribution costs and developing new types of offer for the tourist industry.

The study provides empirical evidence of how the tourist industry could improve and share in the virtual world what it has experienced in the real world. In this context, the paper offers insights into the marketing process of the travel product (e.g. pre- and post-sales, booking) and the management of customer loyalty (e.g. ancillary services).

The value of this paper is to update the knowledge currently available on the distribution channel in the tourism industry taking into consideration the recent evolutions in the structure of travel intermediation.

\section{Literature review}

\subsection{E-commerce and e-tailing: definition and evolution}

The interest of scholars in e-commerce arose at the end of the 1980s with the spreading of electronic information systems and the Internet (Bakos, 1991; Malone et al., 1987). What attracted the attention of companies from 
the very beginning was the economic potential deriving from factors such as global connectivity, interactivity, flexibility, speed, low costs and ease of access to information (Pyle, 1996; Jones and Vijayasarathy, 1998).

Considering the Internet as a place of information, Bakos (1997) identifies the electronic marketplace as the information system that allows participants, buyers and sellers to exchange information on the market about the prices and the products offered. Apart from the ease of access to information, the other special characteristic of e-commerce lies in the interaction between the parties (Yoo et al., 2010; Blasco-Arcas et al., 2014). Internet cancels the concepts of space and time, becoming a new meeting place for supply and demand that is open $24 / 7$ and allows the market's spacetime horizons to be extended.

The spreading of the web and the development of e-commerce are the phenomena that have reshaped and are continuing to reshape companies' marketing strategies. E-commerce on a global level grew by about $20 \%$ in 2014, reaching a value of approximately 1,500 billion euros with a billion e-shoppers (European B2C E-commerce Report, 2014). The factors driving such a development are the increase in the frequency of online purchasing, the increase in the number of users with access to the Internet and the spreading and use of mobile devices such as smartphones and tablets.

In this scenario, Europe boasts 264 million e-shoppers for a value of 363.1 billion euros and an average spending per capita of about 1,376 euros. In Italy, e-commerce has reached a quota of 22.3 billion euros with a growth rate of $6 \%$ of total sales. The growth rate is supported by the rate of penetration of Internet which has reached $82 \%$ and by the increase in the number of users of smartphones (+30\%) and tablets $(+156 \%)$.

The development of the electronic channel has been facilitated by the presence of several advantages both for companies and for consumers. As far as the companies are concerned, the main advantages are fewer barriers to entry, greater efficiency of the production, sales and distribution process, the overcoming of geographical and temporal boundaries, greater interaction with the customer and the possibility to acquire more information regarding buying behavior (Bakos, 1991; Pyle, 1996; Jones and Vijayasarathy, 1998; Foglio, 2010; Sciarelli and Vona, 2000). For the consumer, the benefits deriving from e-commerce are economic advantages, convenience, the availability of information, the customization of the commercial offers, bilateral interaction, the wide choice of products and services (Yoo et al., 2010; Blasco-Arcas et al., 2014).

Defined as the sale or purchase of products and services via the Internet, e-commerce assumes various forms that differ according to the actors participating in the transaction: a) Business to Consumer (B2C) which entails the sale of goods and/or services by the company to the final customer. It represents the most significant quota of the market and includes specialized and generic operators, click and mortar, virtual outlets; b) Business to Business (B2B) which entails the sale of goods and/or services from one company to another; c) Consumer to Consumer (C2C) which entails the sale or the exchange of goods and/or services between private individuals; d) Consumer to Business (C2B) which entails an exchange of information and/or knowledge between private individuals and companies.
Mauro Cavallone

E-tailing as an evolution of the distribution channel in tourism 
sinergie Vol. 34, N. 100, 2016

In this instance, e-tailing represents a true distribution channel and as such has developed both direct and indirect transactions.

In the direct channel, the producers sell to their buyers through their website thanks to an e-commerce section. The products are displayed as if they were in a shop window with images, information, prices and everything the buyer needs in order to make the purchase. In this case, the manufacturing companies (click and mortars) not only have the possibility to sell directly to their customers, but also to give and receive information. Apart from the sales, the website becomes the place where the customers can acquire all the information necessary in order to do their shopping in the strict sense of the word and where the companies can obtain useful data for sales and marketing purposes.

On the contrary, in the indirect channel, manufacturers sell to their customers via digital distributors which may specialize in one category of commodity or in many products. These online platforms are known as e-marketplaces and represent virtual places of intermediation between supply and demand. On these sites it is possible to receive all the information necessary concerning a product or a service and proceed to purchase it. The experiential dimension of the purchase does not represent an obstacle as it is regained by visiting the sales point before taking the final decision. This purchasing process, known as online/offline/online is one of the principal factors for the growth of e-tailing particularly in the tourism industry.

The e-tailing strategies may differ according to the companies' objectives, but it is the opinion of some scholars that owing to their interactivity, they allow positive effects to be achieved on the relationships with customers (Wang et al., 2002) and on their satisfaction (Yoo et al., 2010). Of particular importance is the ability of the company to create an e-commerce site or to rely on an e-tailer who encourages a biunique communication between the company and the customer and an easy-to-use interface. The possibility of interacting directly with the company or with the opinions of past customers overcomes consumers' mistrust, encouraging them to buy. The same also applies for the ease of understanding the website and the purchasing methods. A topic which is acquiring increasing importance amongst companies is how to improve the user experience on their website in order to eliminate the virtual architectural barriers to the purchase, guaranteeing, as a result, more conversions.

\subsection{E-tourism}

Sheldon (1997) and Werthner and Klein (1999) stated that Information and Communication Technology (ICT) has revolutionized travel and tourism. Longhi (2008) remarked that tourism is the most important economic sector of the e-commerce channel. Buhalis and Law (2008) wrote a review on the topic of electronic tourism as the application of ICTs on the tourism industry, while Hikkerova (2010) stated that e-tourism produces and distributes tourist products and services through the digitalization of all the activities involved in the value chain of travel and hospitality industries. Xiang et al. (2015) defined the tourism product as intangible, experiential, and perishable. 
The expanding use of the Internet has radically changed the different stages in the sale of the tourism product as well as the customer service management, by creating "the communication of offers in the pre-sales stage, interactive trade and booking systems in the sales stage, and alterations to bookings, the sale of adjunct services and customer loyalty schemes in the post-sales stage" (Raffour, 2003). At the same time, Internet represents the perfect platform on which tourists can easily and rapidly find all the essential information needed for organizing their travel such as prices, availability, timetable, and customized packages (Antonioli Corigliano and Baggio, 2010). Buhalis and Licata (2002) brought into focus and highlighted the actors involved in these online services: in the e-tailing channel, tourism suppliers (such as airlines, car rental companies and hotels) capitalized on the new opportunities created by ICT and developed websites where users can access their reservation systems directly.

Over the last decades, the tourism distribution agents have been the socalled intermediaries: the traditional offline travel agents, the tour operators and the newborn online travel agencies, which are, indeed, supported by computer reservation systems (CRSs) and global distribution systems (GDSs) (Buhalis and Licata, 2002). The development of the Internet has led to the creation of new fundamental tools for online tourism i.e. the search engines which facilitate travelers' access to tourism products and services. These latter tools, with the CRSs and the GDSs, are the agents in charge of all the activities of the value chain related to the travel product, especially marketing, distribution and customer services (Xiang et al., 2015).

\section{Methodology and results}

\subsection{Dataset description}

In order to examine more closely the role of e-tailing as an evolution of the distribution channel in tourism, we have conducted a quantitative study with a random sample of Italian and American customers. To understand the characteristics and preferences of online customers, the questionnaire was chosen as the best instrument to investigate online tourism purchasing.

Primary data were collected directly through the distribution of an online questionnaire to gather some initial information about consumers' perceptions of the online distribution channel and online tourism industries. The questionnaire began with questions regarding a broader overview of e-tailing and was based on structured questions about participants' purchasing habits, their preferences in buying products online rather than in offline stores and their level of satisfaction and of concern regarding online purchasing and paying. Other structured questions were submitted to narrow the study to the online tourism industries, aiming at observing customers' use of online travel agencies, the use of other search engines, the so-called meta-search engines (e.g. skyscanner.com, kayak.com), their purchase of deals on coupon websites and the way tourists plan their travel: if they use these engines exclusively for the initial travel research and later purchase each service separately in the corresponding companies' websites 
sinergie Vol. 34, N. 100, 2016

or if they use them for the travel research and then they buy the travel directly there. A couple of questions regard the more recent trends created by the use of social media like blogs and other websites dealing with feedbacks and opinions (e.g. TripAdvisor).

The questionnaire included the measurements of 22 variables. The items of some questions were calculated using a five-point Likert-type scale, with anchors ranging from 1 (the lowest) to 5 (the highest). Some subjective questions were also included in order to compare the answers of people of different nationalities.

Regarding the sample used in this project, the survey involved 257 participants and was filled in online and $80.7 \%$ of the respondents were young people up to the age of 25. According to Buhalis and Law (2008), young people are the main Internet users (up to 90\%) in daily life. They grew up in the age of the new media and the use they make of the Web greatly influences online business (Turban et al., 2008).

\subsection{Results}

\subsubsection{General characteristics of the respondent customers}

This section explains the background characteristics of the respondents. A total of 257 online consumers participated in this study. Of the respondents, $72.4 \%$ (corresponding to 186 respondents) were Italian and $23.7 \%$ (corresponding to 61 respondents) were American (Figure 1).

Fig. 1: Gender of the respondent customers

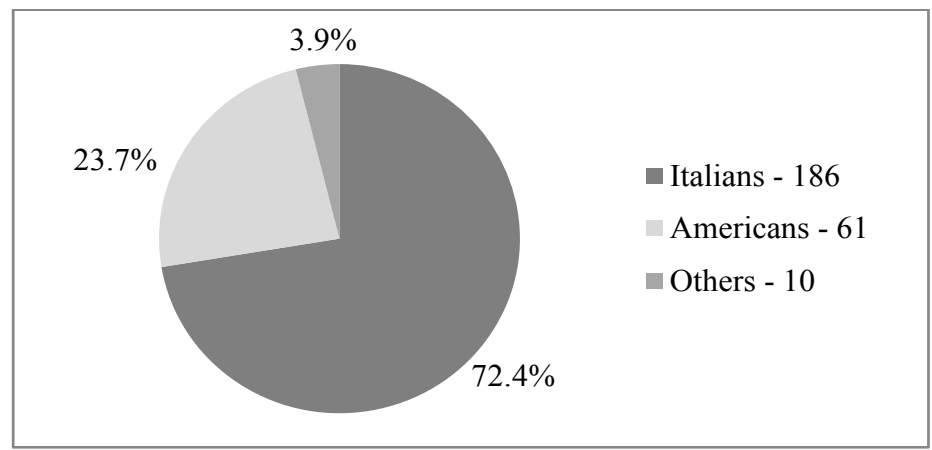

Source: Author's elaboration

In terms of gender, $74.7 \%$ (corresponding to 192 respondents) were female and the remaining $25.3 \%$ (corresponding to 65 respondents) were male.

As can be seen in Figure 2, the majority of customers (52.5\%) ranged from 22 to 25 years in age. In second place, are people aged 18-21 with a frequency of $28.4 \%$, followed by people aged $26-40$ with a frequency of $16.3 \%$. A smaller percentage (2.7\%) is represented by people aged over 40 . 
Fig. 2: Age of the respondent customers

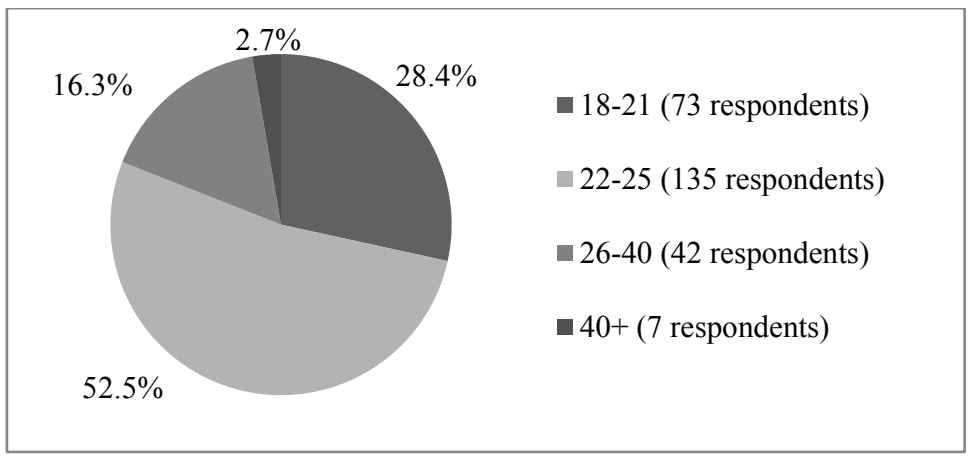

Mauro Cavallone

Michele Modina

E-tailing as an evolution

of the distribution channel

in tourism

Source: Author's elaboration

Concerning online shopping, a far greater majority of respondents $(80 \%$ corresponding to 204 respondents) usually buys online. On one hand, travel represents the service that is most often bought online: $64.8 \%$ of consumers (corresponding to 162 respondents) buy travel and holidays solely online. On the other hand, groceries represent the purchases most often made in store: $93.5 \%$ of consumers (corresponding to 230 respondents) are accustomed to in store grocery shopping.

\subsubsection{Factors that affect online purchasing and online tourism purchasing}

Our research began by interpreting the major factors that drive people to choose online purchasing rather than offline shopping. More than any other factors, both Italian and American customers search for online services as a result of their convenience, availability and broader choice. In a five-point Likert-type scale, respondents perceived "convenience" and "availability" as the most important factors that prompted them to buy online products and services, rating them with five points (highest range). Using the same measurement scale, they considered "security of payment" and "impossibility to check (or try on) products and services" the fundamental drivers that concern them the most while shopping online.

We distributed a subject question, in order to understand the different Italian and American consumer habits in online shopping, asking the respondents which type of goods and services they usually purchase online. American respondents listed books, electronic accessories, handmade crafts, music, clothes and shoes, cosmetics, household goods, sport and concert tickets.

Italians respondents listed jewelry and accessories, event tickets, transport tickets, pet food, mobile apps, coupons and deals, cosmetics, and gadgets (such as phone cases).

Concerning the general characteristics of respondents buying online tourism services, of the total of 257 respondents, the large majority (91.1\%) are accustomed to buying hospitality services through the web. Among the reasons for not buying on the Internet, those who are not used to shopping 
sinergie Vol. 34, N. 100, 2016

online declared fear of fraud, negative past experiences and preference for buying tourism services while traveling and not in advance.

In terms of travel and trip organization, the majority (86\%) of participants buys each service separately (i.e. flights, hotels, transport) on the hospitality companies' websites on their own, without relying on an online travel agency (Figure 3). Indeed, it appears that $63.8 \%$ of travelers use tourism search engines and travel agencies exclusively for the initial travel research and then they purchase each service separately on the corresponding companies' websites.

Fig. 3: Online tourism purchasing

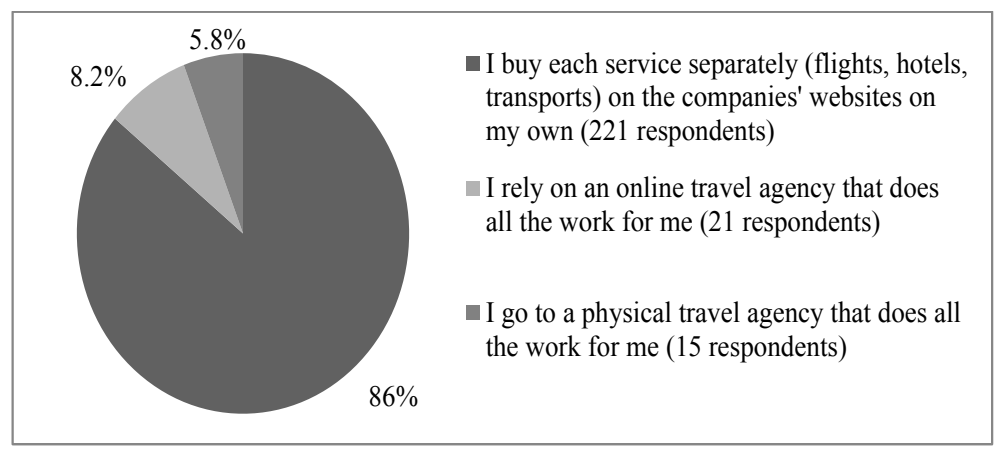

Source: Author's elaboration

\subsubsection{Factors driving the use of tourism websites and social channels}

We asked participants to answer some questions about which kinds of online travel agencies they had or had not already heard about and which kinds they had used more often. On one hand, it emerged that Americans usually consult Expedia as an online travel agency (OTA), while they use Kayak as a meta-search engine for online tourism booking. Americans often rely on other OTAs, which are Hostelworld, Airbnb, Travelocity and Hipmunk, as was suggested in the subject questions. On the other hand, it appears that Italians prefer to employ Booking as an online travel agency, while they use Kayak and Skyscanner as meta-search engines. In the open questions, Italian consumers made reference to other OTAs, such as Hostelworld, Airbnb, Viaggiare, Alpitour, Yalla Yalla, Volagratis and Voyage Privé.

We also asked participants whether they searched online for opinions and feedbacks on websites' reliability before making payment: $67.3 \%$ of respondents always do it, followed by $28 \%$ of them who sometimes do it. Among these, $79.8 \%$ of respondents use TripAdvisor for this purpose.

As can be seen in Figure 4, in a five-point Likert-type scale, respondents answered that they use it to read some opinions regarding people's past experiences, rated with five points (highest range). Using the same measurement scale, they gave a one-point rating (lowest range), stating that they seldom use it to write their own feedbacks after they have experienced a service. 


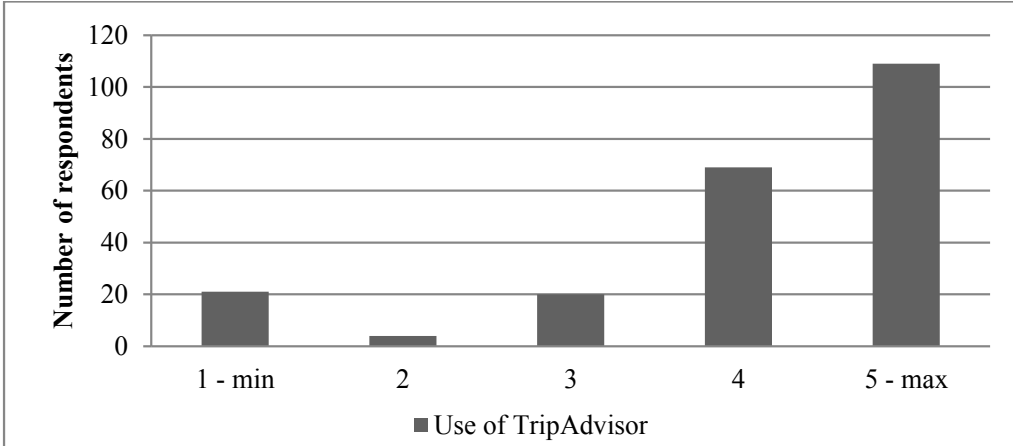

Source: Author's elaboration

The last part of the survey dealt with the recent phenomenon of social channels, such as Groupon and other websites selling deals online. We asked participants whether they buy coupons and deals on Groupon, and only $48.2 \%$ of them answered positively. Among these respondents, only $20.2 \%$ were Americans, and the remaining 99 respondents were divided into 93 Italians, one German, one British, one Romanian and one Spanish user. The reason for this choice is probably driven by the fact that they had had experience of coupons and deals that had not satisfied them: $35.8 \%$ of the respondents were disappointed or would prefer to buy services and products at full price.

In a five-point Likert-type scale, it emerged that respondents usually buy coupons and deals for restaurant services, rated with five points (highest range). An important outcome is that they seldom buy coupons for travel deals, rated with one point (lowest range).

We distributed a subject question, in order to understand the differences between the Italian and American use of social channels. We asked respondents which other kinds of websites selling deals like Groupon they knew. American consumers reported Living Social, Yelp, The Addsheet and Amazon, while Italians stated Groupalia, Kauppa, LetsBonus, Scontamelo, Poinx, Privalia and Tippest. Given these answers, it can be seen that Italian respondents use social channels more often in order to save money and find the best offers.

\section{Conclusions}

\subsection{Discussion and managerial implications}

The evidence emerging from the analysis performed highlights how technological innovation has changed the relationship between company and customer and the buying behavior of the latter in the tourism industry.

As far as the new model of relationship with the customer is concerned, the new ITC tools play an important role in communicating and promoting 
sinergie Vol. 34, N. 100,2016

the brand and in winning customers. In this area, the drivers of an effective marketing strategy in the tourism sector can be identified as follows:

- be found on the web: the user must have easy access to travel offers using ordinary tools for surfing the web;

- listen to the voice of the web: it is necessary to understand what is the users' sentiment towards the tourist brand;

- ensure that people speak well of you: setting up ad hoc campaigns is essential for increasing brand awareness and conveying a positive image of the products with regard to the most widely discussed topics (quality, price, ...)

- build a rapport with the customer: use of a social channel and viral diffusion logic enables contact with the customer to be established and maintained.

To be innovative, the marketing strategy must blend the core elements of the brand and the characteristics of the two-way relationship typical of social media with the exclusive experience associated with the buying experience.

In order to be successful, the modern marketing strategy requires the management to implement in an integrated manner the use of the tools available in order to improve the quality of the accessory/ancillary services which are increasingly demanded by the customer (Kotler e Keller, 2008). In this area, it is essential to dedicate to communication adequate technical and professional resources to form teams of experts who are capable of managing the new technologies and skilled in creating innovative, continuative and direct communication methods.

Innovation in the approach to marketing contributes to revolutionizing the approach of the tourist user by means of a three-stage sequence.

The first stage focuses on experience. Digital interfaces extend the ways of interacting with the contents of the communication, enabling new models through which the consumers relate with the products. At the same time, digital channels enable the customers' experience of the brand to be strengthened by integrating all the communication media.

The second stage concentrates on socialization. The users present on the web become media themselves, in other words an instrument of amplification, of viral communication, for spreading the fame of the brand, of its products, of its advertising. Embracing the social media means reaching potential and future customers.

The third stage concerns uniqueness. Providing a service must not be an activity like another, but must satisfy the wish for uniqueness and exclusivity and must be up to, if not beyond, the customers' expectations. The digital channels are a perfect tool for enabling a model which by integrating web channels, social media and the physical channel allow an exclusive communication and sales strategy to be adopted.

The correct implementation of an approach of this type makes the relationship between the actors involved more intense and raises the customer's degree of satisfaction with regard to both the tangible aspects of the relationship (competence, handling of problems, clarity of language, reliability of the offer) and the intangible ones (kindness, proactiveness, quality of the personal relations, courtesy, confidentiality, trust). 
In this context communication becomes a more strategic tool in the marketing mix. The spreading of the web 2.0, the social networks and mobile devices has opened up new prospects for relationships between operators in Mauro Cavallone Michele Modina E-tailing as an evolution of the distribution ch the sector and the potential consumers (Park and Oh, 2012). As suggested by Fyall and Leask (2007), communication with tourists must occur before, during and after the actual visit in order to answer the needs of a varied, constant and sophisticated interaction (Dore and Crouch, 2003; Foley and Fahy, 2004).

Various airline companies have started to use the new technologies in order to answer travelers' needs to receive information in real time. As reported by Park and Oh (2012), Continental Airlines uses instant messaging to offer its passengers a direct and rapid channel of interaction. Another interesting case is that of Korean Airlines (Park and Oh, 2012) which, in order to create a competitive advantage over their competitors, has set up a web marketing campaign. Using Facebook and Twitter, the airline company improves its corporate image and creates bonds with the consumers by offering them the chance to share travel experiences and involves them by means of competitions to elect the most desirable destinations. Furthermore, these instruments are used to obtain detailed information regarding potential consumers, their needs and preferences thanks to the depth and frequency of the communication.

Jet Blue is another success story. The low-cost airline decided to use Twitter as a channel for its customer service. The company managers noticed that their passengers incurred problems due to delays, cancellations and other unforeseen events and they discovered that the information and assistance in the majority of cases were not provided promptly enough. To overcome this problem, they decided to use Twitter to circulate the information that needs to be provided in good time: in this way, the customer service operators reply in real time to the passengers' questions, establishing a more efficient, rapid and informal relationship with them.

The increased use of smartphones and tablets has contributed towards changing communication methods in the tourism sector by the introduction of applications (apps). By means of specially created apps, destinations can be seen in advance by means of virtual tours inside museums or archaeological sites and hotels can be chosen on the basis of interactive tours of the hotel buildings and facilities.

As Birkner stated (2011), apps could prove to be an instrument of communication and promotion for countries which do not have particularly high numbers of visitors. The case of Visit Korea is emblematic: the app includes recommended itineraries, a photo gallery, practical information for international tourists (exchange rates updated in real time, useful phrases in Korean). This instrument is only a part of the integrated web marketing campaign that has seen the Korea Tourism Organization on the main social networks such as Facebook, Twitter and YouTube and which addresses international visitors through the internet site Buzz-Korea.com.

Another example of integrated communication which benefits from the advantages of technological innovation is represented by Expedia, the website founded by Microsoft in 1996, where users can book plane tickets, hotels, hire cars, cruises, package holidays and various services by Internet 
Sinergie Vol. 34, N. 100, 2016

or phone. To involve potential customers while choosing the hotels and to provide more useful information for choosing the place to stay, Expedia has created expediahotel.view.com, which combines reviews from users with photos from their Flickr profile, Google Street View so that the exact location can be pinpointed, with a description of the strong points, thus guiding the tourist in an interactive way.

Bearing in mind that some of the aspects of communication (e.g. transparency, speed of the replies) are amongst the key factors influencing purchasing preferences, it seems clear that the tourism industry must strengthen its investment in communication in order to build a longlasting relationship with its customers. Effective written communication (letters, bank statements) in verbal contacts (telephone), in advertising (notices, posters), on the Internet and on social media, is a tangible means for promoting the loyalty and satisfaction of the consumer (Howcroft et al., 2003).

\subsection{Limitations and future research}

As with all research, some limitations of this study must be recognized. The present study suffers from a small sample size and a selection process that cannot be representative of the larger population of tourist customers. Hence, the results from the current study cannot be generalized to this wider community. Therefore, further analysis will be necessary to corroborate the findings adequately and also investigate whether our results are typical for other actors (e.g. travel agencies).

This paper opens up several avenues of potential future research. In fact, an opportunity is presented to seek out new data which permit the validity of our results to be extended and to evaluate whether the findings are reflected in different tourist clusters and also in different countries. This could lead to a more comprehensive understanding and knowledge of the specific role that e-tailing could play in achieving a shared value creation within the tourism industry.

\section{References}

ANTONIOLI CORIGLIANO M., BAGGIO R. (2010), Internet e Turismo 2.0, Egea, Milano.

BAKOS J.Y. (1991), “A Strategic Analysis of Electronic Marketplaces," MIS Quarterly, vol. 15, n. 3, pp. 295-310.

BAKOS J.Y. (1997), "Reducing buyer search costs - Implication for electronic marketplaces”, Manangement Science, vol. 43, n. 12, pp. 1676-1692.

BIRKNER C. (2011), "Going the Distance. Adventures in Destination Marketing", Marketing News, May, pp. 12-15.

BLASCO-ARCAS L., HERNANDEZ-ORTEGA B., JIMENEZ-MARTINEZ J. (2014), "Collaborating online - The roles of interactivity and personalization”, The Service Industries Journal, vol. 34, n. 8, pp. 677-698. 
BUHALIS D., LAW R. (2008), "Progress in information technology and tourism management: 20 years on and 10 years after the Internet - The state of eTourism research", Tourism management, vol. 29, n. 4, pp. 609-623.

BUHALIS D., LICATA M.C. (2002), “The future eTourism intermediaries”, Tourism Management, vol. 23, n. 3, pp. 207-220.

BUHALIS D., SOO H.J. (2011), "E-Tourism", Contemporary Tourism Reviews, Goodfellow Publishers Limited, Oxford.

DOHERTY N.F., ELLIS-CHADWICK F. (2010), "Internet retailing: the past, the present and the future", International Journal of Retail and Distribution Management, vol. 38, n. 11/12, pp. 943-965.

DORE L., CROUCH G.I. (2003), "Promoting Destinations: An exploratory study of publicity programmes used by national tourism organisations", Journal of Vacation Marketing, vol. 9, n. 2, pp. 137-151.

EUROPEAN B2C E-COMMERCE REPORT (2014), www.adigital.org/sites/default/ files/ studies/european-b2c-ecommerce-report-2014.

FOGLIO A. (2010), E-commerce e web marketing. Strategie di Web marketing e tecniche di vendita in Internet, Franco Angeli, Milano.

FOLEY A., FAHY J. (2004), "Incongruity Between Expression and Experience: The role of imagery in supporting the positioning of a tourism destination brand", Journal of Brand Management, vol. 11, n. 3, pp. 209-217.

FYALL A., LEASK A. (2007), "Destination marketing: Future issues - Strategic challenges", Tourism and Hospitality Research, vol. 7, n. 1, pp. 50-63.

HIKKEROVA L. (2010), "E-tourism: players and customer behavior", Problems and Perspectives in Management, vol. 8, Special Issue, pp. 45-51.

HOWCROFT J.B., HEWER P., DURKIN M. (2003), “Banker-customer interactions in financial services", Journal of Marketing Management, vol. 19, n. 9/10, pp. 1001-1020.

JONES J.M., VIJAYASARATHY L.R. (1998), "Internet consumer catalog shopping: findings from an exploratory survey and directions for future research", Internet Research, vol. 8, n. 4, pp. 322-330.

KOTLER P., KELLER K. (2008), Marketing Management,13th edition, Prentice Hall, New Jersey.

LONGHI C. (2008), "Usages of the internet and e-tourism. Towards a new economy of tourism", Archive ouverte en Science de l'Homme et de la Société, https:// halshs.archives-ouvertes.fr/halshs-00277767/document.

MALONE T.W., BENJAMIN R.I., YATES J. (1987), "Electronic Markets and Electronic Hierarchies: Effects of Information Technology on Market Structure and Corporate Strategies," Communications of the ACM, vol. 30, n. 6, pp. 484-497.

PARK J., OH I.K. (2012), "A Case Study of Social Media Marketing by Travel Agency: The Salience of Social Media Marketing in the Tourism Industry", International Journal of Tourism Sciences, vol. 12, n. 1, pp. 93-106.

PYLE R. (1996), "Electronic Commerce and the Internet", Communications of the ACM, vol. 39, n. 6, pp. 22-24.

RAFFOUR G. (2003), "E-tourisme interactif. Les enjeux des infomédiations sur l'offre et la demande touristiques", Editions Documentation Française Collection SET-CNT, Mai.

SCIARELLI S., VONA R. (2000), L'impresa commerciale, McGraw Hill, Milano.

SHELDON P. (1997), Tourism information technologies, CAB, Oxford. 
sinergie Vol. 34, N. 100, 2016

TURBAN E., KING D., MCKAY J., MARSHALL P., LEE J., VIEHLAND D. (2008), Electronic Commerce: A Managerial Perspective, Pearson-Prentice Hall, Upper Saddle River, NJ.

WANG F., HEAD M., ARCHER N. (2002), "E-tailing: An analysis of Web Impacts on the Retail Market", Journal of Business Strategies, vol. 19, n. 1, pp. 73-93.

WERTHNER H., KLEIN S. (1999), Information technology and tourism: a challenging relationship, Springer-Verlag, Wien.

XIANG Z., MAGNINI V.P., FESENMAIER D.R. (2015), "Information technology and consumer behavior in travel and tourism: Insights from travel planning using the internet", Journal of Retailing and Consumer Services, vol. 22, n. 1, pp. 244-249.

YOO W.S., LEE Y., PARK J. (2010), "The role of interactivity in e-tailing: Creating value and increasing satisfaction", Journal of Retailing and Consumer Services, vol. 17, n. 2, pp. 89-96.

\section{Academic or professional position and contacts}

\section{Mauro Cavallone}

Associate Professor of Management

University of Bergamo - Italy

e-mail: mauro.cavallone@unibg.it

\section{Michele Modina}

Associate Professor of Management

University of Molise - Italy

e-mail:michele.modina@unimol.it

sinergie italian journal of management ISSN 0393-5108 DOI $10.7433 / \mathrm{s} 100.2016 .06$

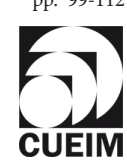

